\title{
FIRST EVIDENCE OF ALTERED SENSORY QUALITY IN A SHELLFISH EXPOSED TO DECREASED pH RELEVANT TO OCEAN ACIDIFICATION
}

\author{
SAM DUPONT, ${ }^{1 *}$ EMILIE HALL ${ }^{2}$ PIERO CALOSI ${ }^{2,3}$ AND BENGT LUNDVE ${ }^{4}$ \\ ${ }^{1}$ Department of Biological and Environmental Sciences, University of Gothenburg, 566 Kristineberg, \\ Fiskebäckskil 45178, Sweden; ${ }^{2}$ School of Marine Science and Engineering, Plymouth University, \\ Plymouth PL4 8AA, UK; ${ }^{3}$ Département de Biologie, Chimie et Géographie, Université du Québec à \\ Rimouski, Rimouski QC G5L 3A1, Canada; ${ }^{4}$ The Sven Lovén Centre for Marine Sciences-Kristineberg, \\ University of Gothenburg, 566 Kristineberg, Fiskebäckskil 45178, Sweden
}

\begin{abstract}
Understanding how seafood will be influenced by coming environmental changes such as ocean acidification is a research priority. One major gap in knowledge relates to the fact that many experiments are not considering relevant end points related directly to production (e.g., size, survival) and product quality (e.g., sensory quality) that can have important repercussions for consumers and the seafood market. The aim of this experiment was to compare the survival and sensory quality of the adult northern shrimp (Pandalus borealis) exposed for $3 \mathrm{wk}$ to a temperature at the extreme of its thermal tolerance $\left(11^{\circ} \mathrm{C}\right)$ and $2 \mathrm{pH}$ treatments: $\mathrm{pH} 8.0$ (the current average $\mathrm{pH}$ at the sampling site) and $\mathrm{pH} 7.5$ (which is out of the current natural variability and relevant to near-future ocean acidification). Results show that decreased $\mathrm{pH}$ increased mortality significantly, by $63 \%$. Sensory quality was assessed through semiqualitative scoring by a panel of 30 local connoisseurs. They were asked to rate 4 shrimp ( 2 from each $\mathrm{pH}$ treatment) for 3 parameters: appearance, texture and taste. Decreased $\mathrm{pH}$ reduced the score significantly for appearance and taste, but not texture. As a consequence, shrimp maintained in $\mathrm{pH} 8.0$ had a 3.4 times increased probability to be scored as the best shrimp on the plate, whereas shrimp from the $\mathrm{pH} 7.5$ treatment had a 2.6 times more chance to be scored as the least desirable shrimp on the plate. These results help to prove the concept that ocean acidification can modulate sensory quality of the northern shrimp P. borealis. More research is now needed to evaluate impacts on other seafood species, socioeconomic consequences, and potential options.
\end{abstract}

KEY WORDS: pH, acidification, taste, texture, appearance, northern shrimp, Pandalus borealis

\section{INTRODUCTION}

The ocean contributes significantly to society. Dependence on marine protein is expected to continue to rise with the increasing human population; world capture fisheries and aquaculture are estimated to provide food to 4.3 billion people with at least $15 \%$ of their animal protein. During the past $30 \mathrm{y}$, world food production by aquaculture has expanded 12-fold - nearly half of the human seafood production. Understanding how seafood production and quality will be influenced by coming environmental changes is critical. The economic consequences of a collapsing fishery and aquaculture industry would be dire indeed.

Ocean acidification is a rapid and unprecedented increase in ocean acidity. Intensive fossil-fuel burning and deforestation during the past 2 centuries has increased atmospheric $\mathrm{CO}_{2}$ to almost $40 \%$ above preindustrial values. The global ocean currently absorbs around $30 \%$ of released anthropogenic $\mathrm{CO}_{2}$, fundamentally altering ocean chemistry by acidifying seawater. It is predicted that average oceanic $\mathrm{pH}$ will decrease by $0.4 \mathrm{pH}$ units by 2100 , a rate of change 100 times faster than anything seen in the past hundreds of millennia (Caldeira \& Wickett 2003). Together with other stressors such as global warming, it challenges marine species and ecosystems (Dupont \& Pörtner 2013, Wittmann \& Pörtner 2013). Despite a growing body of evidence demonstrating that ocean acidification is a major threat for seafood security (availability of sustainable and good-quality seafood), and recommendations that species and end points with direct economic importance should be prioritized (Hilmi et al.

*Corresponding author. E-mail: sam.dupont@ bioenv.gu.se DOI: $10.2983 / 035.033 .0320$
2014), consequences for seafood remain unclear. One exception is the affect of ocean acidification on oyster production in hatcheries located on the northern West Coast of the United Statesa US\$270 million industry. A significant decline in the survival of oyster larvae since 2005 appeared to be connected to nearshore ocean acidification (Barton et al. 2012).

One major gap in knowledge relates to the fact that many experiments are not considering relevant end points. To make any projection on future effects of ocean acidification and other environmental challenges on seafood, it is critical to consider parameters that are related directly to production (e.g., survival) and quality (e.g., sensory quality). The aim of this experiment was to test on the northern shrimp (Pandalus borealis) the impact on survival and sensory quality of $3 \mathrm{wk}$ of exposure to a temperature at the extreme of its thermal tolerance $\left(11^{\circ} \mathrm{C}\right)$ and $\mathrm{pH}$ conditions within $(\mathrm{pH} 8.0)$ and outside $(\mathrm{pH} 7.5)$ of the current range of $\mathrm{pH}$ variability.

The northern shrimp is a keystone species in the marine ecosystem of the continental shelves in the North Atlantic and is an important prey for demersal fish species, most notably cod. It also has substantial economic (e.g., $€ 100$ million for Norway alone [Søvik \& Thangstad 2013]) as well as high cultural value as seafood for the public. Shrimp are famous for their sensory appeal, including their appearance, texture, and flavor.

The future of shrimp as a harvested resource is unsure (Wieland et al. 2012). Shrimp landings have declined in the northwest Atlantic. The decline may be caused by recruitment failure caused by mismatch between timing of phytoplankton bloom and hatching of larvae (Koeller et al. 2009), as well as by increased predator abundance. Previous work on Pandalus borealis demonstrated that the species is relatively tolerant to 
ocean acidification (Bechmann et al. 2011, Arnberg et al. 2013, Hammer \& Pedersen 2013). Decreased $\mathrm{pH}(\Delta \mathrm{pH}=0.5)$ induced a delay in development but had no impact on mortality (Bechmann et al. 2010, Arnberg et al. 2013). As adults, the northern shrimp was able to compensate for extreme acidification $(\Delta \mathrm{pH}=1.2)$ for up to 16 days and without any documented consequence for mortality (Hammer \& Pedersen 2013). All these studies were performed at temperatures ranging from $5-9.5^{\circ} \mathrm{C}$. The shrimp $P$. borealis is found primarily at low temperatures $(0$ $5^{\circ} \mathrm{C}$ ), but it shows a wide temperature range as an adult and can live at temperatures as warm as $12^{\circ} \mathrm{C}$, which is experienced in the North Sea (Allen 1959, Bergstrom 2000). Organisms specialize within certain temperature ranges and are sensitive to extremes (Magozzi \& Calosi 2014). It can be predicted that exposure to temperatures at the limit of thermal tolerance will enhance sensitivity to stress, including ocean acidification (Pörtner \& Farrell 2008, Dupont \& Pörtner 2013). It is also well established that environmental factors causing stress can affect the quality of meat. For example, stressed fish can have a metallic aftertaste (Borderías \& Sánchez-Alonso 2011). As a consequence, our hypothesis was that ocean acidification will increase shrimp stress level with negative consequences for their survival and sensory eating quality.

\section{MATERIALS AND METHODS}

\section{Animal Collection}

Adult females of the northern shrimp (Pandalus borealis) were sampled on April 24 and 25, and May 13 from central Gullmarsfjord $\left(58^{\circ} 20^{\prime} 26.1^{\prime \prime} \mathrm{N}, 11^{\circ} 33^{\prime} 31.7^{\prime \prime}\right.$ E) and close to Brofjorden (58 $\left.18^{\prime} 12.4^{\prime \prime} \mathrm{N}, 11^{\circ} 17^{\prime} 59.7^{\prime \prime} \mathrm{E}\right)$ using an otter trawl at $85-110 \mathrm{~m}$ for $30-60 \mathrm{~min}$. As soon as they were onboard, the shrimp were transferred to chilled, aerated tanks for transportation to minimize exposure to thermal fluctuations. At The Sven Lovén Center for Marine Sciences-Kristineberg, they were kept in basins with flowing deep-sea water (temperature, $8^{\circ} \mathrm{C}$; salinity, 33) until the beginning of the experiment (June 11) and were fed ad libitum on chopped herring (Clupea harengus), blue mussel (Mytilus edulis), Artemia nauplii, and Marine Flake (New Era, Thorne, UK). Residual food was removed regularly to avoid contamination.

\section{Experimental Design and Seawater Chemistry}

Shrimp were maintained in $4 \times 100$-L basins $(2$ replicated basins per $\mathrm{pH}$ treatment; $42-57$ shrimp per basin) with natural flowing seawater and a replacement of $1 \mathrm{~L} / \mathrm{min}$. They were kept at $11^{\circ} \mathrm{C}$, a salinity of 33 , and fed ad libitum with chopped herring every fourth day. The number of living shrimp was noted every fourth day, and dead individuals were removed. $\mathrm{pH}$ was maintained in each experimental basin using a computerized feedback system (AquaMedic) that regulated $\mathrm{pH}$ by adding pure gaseous $\mathrm{CO}_{2}$ directly into the seawater. $\mathrm{pH}$ was measured twice a week on the total scale after calibration using TRIS (Tris/ $\mathrm{HCl}$ ) and AMP (2-aminopyridine/ $\mathrm{HCl}$ ) buffer solutions (provided by Unité d'Océanographie Chimique, Université de Liège, Belgium), and was used to adjust $\mathrm{pH}$ system settings. Total alkalinity was assessed once a week on filtered samples $(0.2 \mu \mathrm{m})$ by titration (TitroLine Alpha Plus, SI Analytics). $p \mathrm{CO}_{2}$ was calculated from total $\mathrm{pH}$ and total alkalinity using CO2SYS (Lewis \& Wallace 1998), with dissociation constants from Mehrbach et al. (1973) refitted by Dickson and Millero (1987). Two nominal $\mathrm{pH}$ treatments were compared: (1) $\mathrm{pH} 8.0$, the current average $\mathrm{pH}$; and (2) $\mathrm{pH} 7.5$, outside of the current range of $\mathrm{pH}$ variability and a relevant scenario for near-future ocean acidification (Dorey et al. 2013). $\mathrm{pH}$ and $p \mathrm{CO}_{2}$ were significantly different between treatments, with no significant difference between the 2 replicates (Table 1).

\section{Sensory Evaluation}

After 3 wk of exposure, shrimp were sampled and prepared for the tasting assessment. More than 30 shrimp were collected from each basin and prepared under the supervision of a professional chef (Kirsten Johannsen). Shrimp from each basin were cooked by immersion for $3 \mathrm{~min}$ in $2 \mathrm{~L}$ boiling water made from the same stock of surface seawater with $60 \mathrm{~g}$ of sea salt/L (per local industry standard). Shrimp were then rinsed in cold surface seawater and cooled to room temperature for $1 \mathrm{~h}$. Thirty plates were prepared with shrimp from the 4 basins assigned randomly to 4 different positions on each plate (1-4) so tasters could not influence each other. Shrimp length varied between $8.6 \mathrm{~cm}$ and $13.9 \mathrm{~cm}$ and were selected visually to minimize size difference within each plate (maximum size variation, $11.6 \%$ ).

A panel of 30 local voluntary connoisseurs was gathered at The Sven Lovén Center for Marine Sciences-Kristineberg (sex ratio, 1:1; age, $42 \pm 2$ y old; age range, 24-56 y). All of them confirmed liking shrimp and eat shrimp $1.76 \pm 0.21$ times a month (between 4 times a month and 4 times a year). The sensory evaluation was blinded, and tasters were not informed of the design of the experiment. Each taster received a plate and was asked to score the 4 shrimp (range, 1 [bad]-5 [excellent]) based on 3 criteria: appearance, texture, and taste. They were

TABLE 1.

Seawater chemistry in the $2 \mathrm{pH}$ treatments (measured $\mathrm{pH}_{\mathrm{T}}$ and calculated $p \mathrm{CO}_{2}$ from $\mathrm{pH}_{\mathrm{T}}$ and $\mathrm{A}_{\mathrm{T}}=2,260 \pm 56 \mu \mathrm{mol} / \mathrm{kg} \mathrm{SW}$ ).

\begin{tabular}{|c|c|c|c|c|c|}
\hline & \multicolumn{2}{|c|}{ Nominal pH } & \multicolumn{3}{|c|}{ ANOVA 2} \\
\hline & 8.0 & 7.5 & Model & pH treatment & Replicate \\
\hline $\mathrm{pH}_{\mathrm{T}}$ & $7.99 \pm 0.01$ & $7.55 \pm 0.01$ & $\begin{array}{c}\mathrm{F}_{3,79}=3484 \\
P<0.0001\end{array}$ & $\begin{array}{c}\mathrm{F}=10,452 \\
P<0.0001\end{array}$ & $\begin{array}{l}\mathrm{F}=0.24 \\
P=0.78\end{array}$ \\
\hline$p \mathrm{CO}_{2}(\mu \mathrm{atm})$ & $459 \pm 5$ & $1,368 \pm 7$ & $\begin{array}{c}\mathrm{F}_{3,79}=3864 \\
P<0.0001\end{array}$ & $\begin{array}{c}\mathrm{F}=10,902 \\
P<0.0001\end{array}$ & $\begin{array}{l}\mathrm{F}=0.20 \\
P=0.82\end{array}$ \\
\hline
\end{tabular}

$\mathrm{A}_{\mathrm{T}}$, total alkalinity; $\mathrm{pH}_{\mathrm{T}}$, total $\mathrm{pH}$. 
also asked if they would be willing to pay more for better tasting shrimp.

\section{Statistical Analyses}

Relative mortality rate expressed in percent per day was calculated for each replicate and $\mathrm{pH}$ treatment as the coefficient of the significant linear relationship between relative density (percent) and time (day). Differences between treatments and replicates were tested using an analysis of covariance model.

Analysis of variance 2 models were used to test differences between $\mathrm{pH}$ treatments and replicates for the sensory evaluation parameters (appearance, texture, taste). These parameters were not based on a standardized scale. As a consequence, differences in scoring between tasters can be expected. To account for these differences, shrimp on every plate were ranked based on the sum of scores for appearance, texture, and taste between 1 point (best shrimp, highest score) and 4 points (worst shrimp, lowest score). For this ranking, difference between $\mathrm{pH}$ treatments and replicates were tested using chi-square statistics.

All statistical analyses were performed using STAT software (SAS Institute). The normality of data distributions was confirmed with a Shapiro-Wilk test, and the homoscedasticity was tested using the Bartlett test. Each mean value is expressed as mean \pm SEM. The significance level applied was $5 \%$.

\section{RESULTS}

Relative mortality rate was, on average, $2.05 \pm 0.23 \%$ day at $\mathrm{pH} 7.5$ and $1.27 \pm 0.24 \%$ day at $\mathrm{pH} 8.0$, which was statistically significant (analysis of covariance model: $\mathrm{F}_{1,15}=16.9, P<0.0001$; $\mathrm{pH}: \mathrm{F}=5.32, P=0.042)$. There were no significant differences between replicates $(\mathrm{F}=0.08, P=0.79)$ or interactions between $\mathrm{pH}$ and replicates $(\mathrm{F}=0.01, P=0.97)$.

On average, shrimp from the $\mathrm{pH}-8.0$ treatment had significantly greater scores for appearance and taste compared with shrimp from the $\mathrm{pH}-7.5$ treatment, with no significant differences between replicates or interactions, or between replicates and $\mathrm{pH}$ treatments. No significant difference was observed for texture (Table 2, Fig. 1).

Significant differences were observed between $\mathrm{pH}$ treatments for the ranking of the shrimp on each plate (chi-square $=25.12$, $P<0.0001$ ), with no differences between replicates within each tested $\mathrm{pH}(\mathrm{pH}$ 8.1: chi-square $=6.33, P=0.10$; $\mathrm{pH} 7.5$ : chisquare $=4.71, P=0.19$ ). Shrimp from the $\mathrm{pH}-8.0$ treatment had 3.4 times more chance to be scored as the best shrimp of the plate (rank 1), whereas the shrimp from the $\mathrm{pH}-7.5$ treatment had 2.6 times more chance to be scored as the least desirable shrimp on the plate (rank 4; Fig. 2).

All but 1 of the 30 voluntary tasters claimed they would be willing to pay more for better quality shrimp.

\section{DISCUSSION}

Our results demonstrate that a 3-wk exposure to decreased $\mathrm{pH}$ related to ocean acidification $(\Delta \mathrm{pH}=0.5)$ can lead to a 1.6 times increase in adult shrimp mortality. This is somewhat in contrast to the conclusions of Hammer and Pedersen (2013), which showed tolerance toward extreme acidosis $(\Delta \mathrm{pH}=1.2)$ in the same species. This could be attributed in part to difference in sensitivity between populations (Sunday et al. 2014). Another difference between the 2 studies is the temperature used.
TABLE 2.

Statistical analyses of the sensory evaluation parameters using an analysis of variance $\mathbf{2}$ model.

\begin{tabular}{lcccc}
\hline \hline & Model & $\mathbf{p H}$ treatment & Replicate & $\mathbf{p H} \times$ replicate \\
\hline Appearance & $\mathrm{F}_{3,119}=2.85$ & $\mathrm{~F}=4.67$ & $\mathrm{~F}=0.11$ & $\mathrm{~F}=0.72$ \\
& $P=0.042$ & $P=0.03$ & $P=0.11$ & $P=0.40$ \\
Texture & $\mathrm{F}_{3,119}=1.63$ & - & - & - \\
Taste & $P=0.19$ & & & \\
& $\mathrm{~F}_{3,119}=6.08$ & $\mathrm{~F}=17.05$ & $\mathrm{~F}=0.91$ & $\mathrm{~F}=0.28$ \\
& $P=0.0007$ & $P<0.0001$ & $P=0.34$ & $P=0.60$ \\
\hline
\end{tabular}

Hammer and Pedersen (2013) conducted their experiment at an optimal temperature $\left(7^{\circ} \mathrm{C}\right)$, whereas we used a temperature at the extreme of the thermal tolerance of the shrimp $\left(11^{\circ} \mathrm{C}\right)$. Response to ocean acidification can be highly dependent on thermal conditions. All organisms live within a limited range of body temperatures as a result of optimized structural and kinetic coordination of molecular, cellular, and systemic processes, and functional constraints result at temperature extremes (Pörtner \& Farrell 2008). It is hypothesized that additional stressors such as ocean acidification have the potential to narrow these thermal windows. This theoretical framework highlights the fact that response to ocean acidification can be highly dependent on thermal conditions. For example, temperature modulated the impact of decreasing $\mathrm{pH}$ on sea urchin larvae, leading to a positive effect of low $\mathrm{pH}$ at the lowest temperature, a neutral effect at optimal temperature, and a negative effect at high temperature (Gianguzza et al. 2014). It is then critical to consider a range of temperatures that considers current temperatures and future environmental variability in any experiment aiming at studying the effect of ocean acidification.

The exposure to decreased $\mathrm{pH}$ also affected the sensory quality of the exposed shrimp negatively, with a significantly lower score for appearance and taste. This led to a 3.4 times increased probability to be scored as the best shrimp of the plate for the ones cultured in $\mathrm{pH} 8.0$, whereas the shrimp from the $\mathrm{pH}-7.5$ treatment had 2.6 times more chance to be scored as the

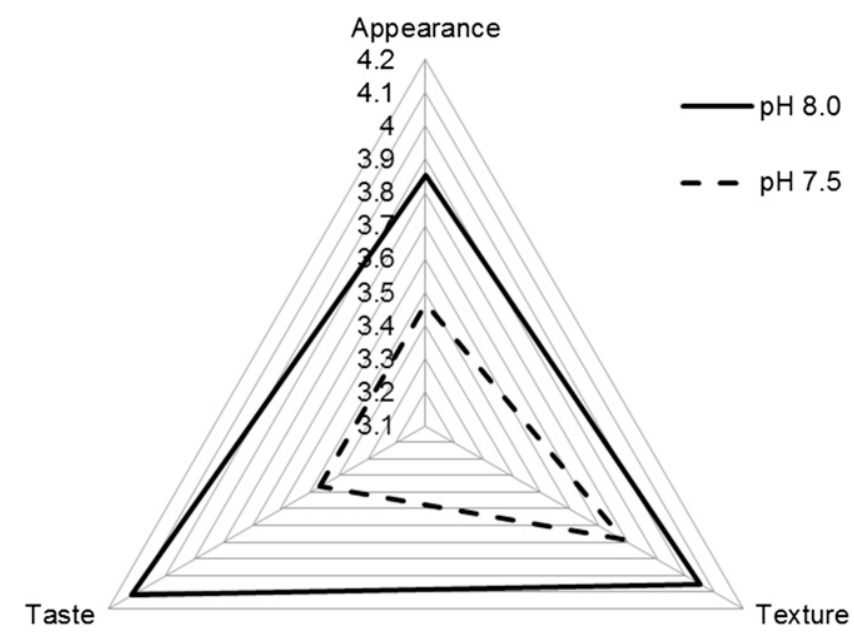

Figure 1. Average scores of the 3 sensory evaluation parameters (appearance, texture, and taste) in the $\mathbf{2} \mathrm{pH}$ treatments. 


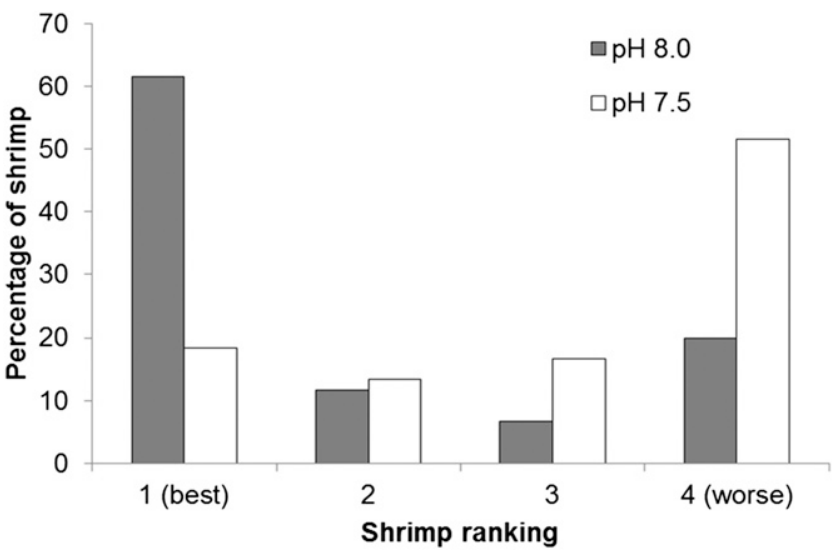

Figure 2. Percentage of shrimp ranking from best (1) to worst (4) on individual plates in both $\mathrm{pH}$ treatments.

worst shrimp on the plate. These results should be considered as a proof of concept that ocean acidification can have an impact on seafood sensory quality that can be detected by local connoisseurs, rather than make any predictions for future shrimp quality. First, our experimental design is only considered short-term exposure (3 wk) and simplistic scenarios (2 stable $\mathrm{pH}$ treatments). More realistic perturbation experiments should consider longer exposure time (ideally, across life history stages and through multiple generations); take into account natural variability in $\mathrm{pH}$ and other relevant local environmental parameters, including food quality and quantity; and allow for adaptation, acclimation, and so forth (e.g., Hilmi et al. 2013, Gaylor et al. 2014, Sunday et al. 2014). Other seafood species should also be considered, because species- and phyla-specific sensitivities have been shown to be extremely different (Wittman \& Pörtner 2013). Second, sensory quality is relative to consumer preference, and this parameter can vary among regions and evolve through time. Last, other assessment methods (e.g., trained panelists, electronic nose, quantitative descriptive analysis [e.g., Mejlholm et al. 2005, Zeng et al. 2005] for Pandalus borealis) and end points (e.g., stress markets, lipid content) should be considered. Research should also be oriented toward solutions. For example, isolation of resilient seafood strains to ocean acidification would allow preparing aquaculture for changes to come. More work is needed to evaluate the impact of ocean acidification on seafood sensory quality and potential economic consequences. For example, taste is one of the key factors influencing consumer behavior (Shyam 2013). This is consistent with the $97 \%$ of our panel list willingness to pay more for better quality shrimp.

The fact that ocean acidification can have a detectable impact on shrimp sensory quality can be a unique opportunity to communicate about global changes effectively. In Scandinavian countries, the Pandalus is extremely popular and an integral part of local folklore and culture. It is then an ideal model to attract citizen's interest (Can you imagine Scandinavia without a shrimp sandwich?, Can you taste climate change?), to initiate the discussion about future threats on their favorite seafood, and to engage them on climate issues (e.g., through reduction of $\mathrm{CO}_{2}$ emissions) and the broader marine biodiversity crisis we may be facing.

\section{ACKNOWLEDGMENTS}

The authors are grateful to chef Kirsten Johannsen who provided her professional expertise and help for cooking the shrimp, and they extend many thanks to Manuela Truebano and Lotti Alvord for their invaluable help during shrimp collection and husbandry, as well as to Gilles Tabutin for his help during the taste event. Shrimp collection was funded by ASSEMBLE, KVA, and TOTAL Foundation grants. S. D. is funded by the Linnaeus Centre for Marine Evolutionary Biology at the University of Gothenburg (http://www.cemeb.science.gu.se/) and a Linnaeus grant from the Swedish Research Councils VR and Formas.

\section{LITERATURE CITED}

Allen, J. A. 1959. On the biology of Pandalus borealis Kroyer, with reference to a population off the Northumberland coast. J. Mar. Biol. Assoc. U.K. 38:189-220.

Arnberg, M., P. Calosi, J. I. Spicer, A. H. S. Tandberg, M. Nilsen, S. Westerlund \& R. K. Bechmann. 2013. Elevated temperature elicits greater effects than decreased $\mathrm{pH}$ on the development, feeding and metabolism of northern shrimp (Pandalus borealis) larvae. Mar. Biol. 160:2037-2048.

Barton, A., B. Hales, G. G. Waldbusser, C. Langdon \& R. A. Feely. 2012. The Pacific oyster, Crassostrea gigas, shows negative correlation to naturally elevated carbon dioxide levels: implications for near-term ocean acidification effects. Limnol. Oceanogr. 57:698-710.

Bechmann, R. K., I. C. Taban, S. Westerlund, B. F. Godal, M. Arnberg, S. Vingen, A. Ingvarsdottir \& T. Baussant. 2011. Effects of ocean acidification on early life stages of shrimp (Pandalus borealis) and mussel (Mytilus edulis). J. Toxicol. Environ. Health A. 74:424-438.

Bergstrom, B. 2000. The biology of Pandalus. Adv. Mar. Biol. 38:55-245.

Borderías, A. J. \& I. Sánchez-Alonso. 2011. First processing steps and the quality of wild and farmed fish. J. Food Sci. 76:R1-R5.

Caldeira, K. \& M. E. Wickett. 2003. Anthropogenic carbon and ocean pH. Nature 425:365.

Dickson, A. G. \& F. J. Millero. 1987. A comparison of the equilibrium constants for the dissociation of carbonic acid in seawater media. Deep-Sea Res. 34:1733-1743.
Dorey, N., P. Lancon, M. Thorndyke \& S. Dupont. 2013. Assessing physiological tipping point for sea urchin larvae exposed to a broad range of pH. Global Change Biol. 19:3355-3367.

Dupont, S. \& H. Pörtner. 2013. Get ready for ocean acidification. Nature 498:429.

Gaylor, B., K. J. Kroeker, J. M. Sunday, K. M. Anderson, J. P. Barry, N. E. Brown, S. D. Connell, S. Dupont, K. E. Fabricius, J. M. HallSpencer, T. Klinger, M. Milazzo, P. L. Munday, B. D. Russell, E. Sanford, S. J. Schreiber, V. Thiyagarajan, M. L. H. Vaughan, S. Widdicombe \& C. D. G. Harley. 2014. Ocean acidification through the lens of ecological theory. Ecology. In press.

Gianguzza, P., G. Visconti, F. Gianguzza, S. Vizzini, S. Gianluca \& S. Dupont. 2014. Temperature modulates the response of the thermophilous sea urchin Arbacia lixula early life stages to $\mathrm{CO}_{2^{-}}$ driven acidification. Mar. Environ. Res. 93:70-77.

Hammer, K. M. \& S. A. Pedersen. 2013. Deep-water prawn Pandalus borealis displays a relatively high $\mathrm{pH}$ regulatory capacity in response to $\mathrm{CO}_{2}$-induced acidosis. Mar. Ecol. Prog. Ser. 492:139-151.

Hilmi, N., D. Allemand, M. Cinar, S. Cooley, J. Hall-Spencer, G. Haraldsson, C. Hattam, J. A. Jeffree, J. C. Orr, K. Rehdanz, S. Reynaud, A. Safa \& S. Dupont. 2014. Exposure of Mediterranean countries to ocean acidification. Water 6:1719-1744.

Hilmi, N., D. Allemand, S. Dupont, A. Safa, G. Haraldsson, P. L. D. Nunes, C. Moore, C. Hattam, S. Reynaud, J. M. Hall-Spencer, 
M. Fine, C. Turley, R. Jeffree, J. Orr, P. L. Munday \& S. R. Cooley. 2013. Towards improved socio-economic assessments of ocean acidification's impacts. Mar. Biol. 160:1773-1787.

Koeller, P., C. Fuentes-Yaco, T. Platt, S. Sathyendranath, A. Richards, P. Ouellet, D. Orr, U. Skúladóttir, K. Wieland, L. Savard \& M. Aschan. 2009. Basin-scale coherence in phenology of shrimps and phytoplankton in the north Atlantic Ocean. Science 324:791-793.

Lewis, E. \& D. Wallace. 1998. Program developed for $\mathrm{CO}_{2}$ system calculations. ORNL/CDIAC. Oak Ridge, TN: Carbon Dioxide Information Analysis Center, U.S. Department of Energy. Accessed September 10, 2014. Available from: ftp://cdiac.ornl.gov/pub/ co2sys/CO2SYS_calc_DOS_v1.05/co2sys_v1.05.txt

Magozzi, S. \& P. Calosi. 2014. Integrating metabolic performance, thermal tolerance, and plasticity enables for more accurate predictions on species vulnerability to acute and chronic effects of global warming. Glob. Change Biol. DOI: 10.1111/gcb.12695.

Mehrbach, C., C. H. Culberson, J. E. Hawley \& R. M. Pytkowicz. 1973. Measurement of the apparent dissociation constants of carbonic acid in seawater at atmospheric pressure. Limnol. Oceanogr. 18:897-907.

Mejlholm, O., N. Bøknæs \& P. Dalgaard. 2005. Shelf life and safety aspects of chilled cooked and peeled shrimp (Pandalus borealis) in modified atmosphere packaging. J. Appl. Microbiol. 99:66-76.
Pörtner, H. O. \& A. P. Farrell. 2008. Physiology and climate change. Science 322:690-692.

Shyam, S. S. 2013. Demand pattern and willingness to pay for high value fishes in India. J. Mar. Biol. Assoc. India 55:48-54.

Søvik, G. \& T. Thangstad. 2013. The Norwegian Fishery for Northern Shrimp (Pandalus borealis) in Skagerrak and the Norwegian Deep (ICES Divisions IIIa and IVa east), 1970-2013. NAFO SCR Doc. 13/066:33. Serial No. N6228. Accessed September 10, 2014. Available from: http://archive.nafo.int/open/sc/2013/scr13-066.pdf

Sunday, J. M., P. Calosi, S. Dupont, P. L. Munday, J. H. Stillman \& T. B. H. Reusch. 2014. Evolution in an acidifying ocean. Trends Ecol. Evol. 29:117-125.

Wieland, K., H. Siegstad, J. M. Casas Sanchez \& D. Orr. 2012. Recent decline of northern shrimp stocks in the Northwest Atlantic: coincidence, multiple causes or response to synchronous changes in the environment? The Ecosystem Studies of Sub-Arctic Seas (ESSAS) Program. Accessed September 10, 2014. Available at: http://www.imr.no/essas/ files/essas_feature_article_wieland_et_al_december_2012.pdf/en

Wittmann, A. \& H. O. Pörtner. 2013. Sensitivities of extant animal taxa to ocean acidification. Nat. Clim. Change. 3:995-1001.

Zeng, Q. Z., K. A. Thorarinsdottir \& G. Olafsdottir. 2005. Quality changes of shrimp (Pandalus borealis) stored under different cooling conditions. J. Food Sci. 70:s459-s466. 